\title{
Hubungan Interaksi Sosial dengan Motivasi Kerja Karyawan PT Perkebunan Nusantara II
}

\section{The Correlation between Social Interaction With Work Motivation Employees at PT Perkebunan Nusantara II}

\author{
Mustika Tarigan $^{(1)}$, Nini Sri Wahyuni(2) \& Rahmat Syaibani(3)* \\ Fakultas Psikologi, Universitas Medan Area, Indonesia
}

Disubmit: 18 Oktober 2020; Diproses: 18 Oktober 2020; Diaccept: 20 November 2020; Dipublish: 01 Desember 2020

*Corresponding autor: Email: mustikatarigan@staff.uma.ac.id

\begin{abstract}
Abstrak
Penelitian ini bertujuan untuk mengetahui dan menguji secara empirik apakah ada hubungan antara interaksi sosial dengan motivasi kerja karyawan PT Perkebunan Nusantara II. Subjek penelitian adalah karyawan yang bekerja di PT Perkebunan Nusantara II yang berjumlah 74 orang. Alat ukur yang digunakan adalah instrumen interaksi sosial yang terdiri dari 40 aitem $(\alpha=0.948)$ dan instrumen motivasi kerja yang terdiri dari 38 aitem $(\alpha=$ 0.906). Analisis data menggunakan teknik $r$ Product Moment. Berdasarkan analisis data, diperoleh bahwa hipotesis yang diajukan dalam peneltian ini dinyatakan diterima, yaitu ada hubungan antara interaksi sosial dengan motivasi kerja karyawan. Artinya semakin baik interaksi sosial maka semakin tinggi motivasi kerja karyawan. Hal ini dibuktikan melalui perhitungan analisis $r$ Product Moment dengan nilai atau koefisien $\left(\mathrm{R}_{\mathrm{xy}}\right)=0.397$ dan koefisien determinan $\left(\mathrm{R}^{2}\right)=0.158$ dengan $\mathrm{p}=0.000<0.050$. Koefisien determinan $\left(\mathrm{R}^{2}\right)=0.158$ menunjukkan bahwa interaksi sosial berhubungan dengan motivasi kerja sebesar 15,8\%. Selanjutnya dilihat dari perhitungan mean hipotetik $=100$ dan mean empirik 119.135 serta standat deviasi $=14.359$ diketahui bahwa interaksi sosial dalam kategori baik. Sedangkan motivasi kerja dari perhitungan mean hipotetik $=95.00$ dan mean empirik 116.648 serta standart deviasi = 12.444 diketahui bahwa motivasi kerja dalam kategori tinggi.
\end{abstract}

Kata Kunci: Interkasi Sosial; Motivasi Kerja; Karyawan

\begin{abstract}
This study aims to determine and empirically test whether there is a correlation between social interaction and work motivation employees at PT Perkebunan Nusantara II. The research subjects were 74 employees at PT Perkebunan Nusantara II. The measuring instruments used were social interaction instruments consisting of 40 items $(\alpha=0.948)$ and work motivation instruments consisting of 38 items $(\alpha=0.906)$. Data analysis using the Product Moment $r$ technique. Based on data analysis, it is found that the hypothesis proposed in this study is accepted, that is, there is a relationship between social interaction and employee motivation. This means that the better the social interaction, the higher the employee's work motivation. This is evidenced by the calculation of $r$ Product Moment analysis with the value or coefficient $(R x y)=0.397$ and the determinant coefficient $(R 2)=0.158$ with $p=0.000<0.050$. The determinant coefficient $(R 2)=0.158$ shows that social interaction is related to work motivation by $15.8 \%$. Furthermore, seen from the calculation of the hypothetical mean $=100$ and the empirical mean 119,135 and the standard deviation = 14,359, it is known that social interactions are in good category. While the work motivation from the calculation of the hypothetical mean $=95.00$ and the empirical mean of 116,648 and the standard deviation =12,444, it is known that the work motivation is in the high category.
\end{abstract}

Keywords: Social interaction; Work Motivation, Employees

Rekomendasi mensitasi :

Tarigan, M., Wahyuni, N.S., \& Syaibani, R., 2020, Hubungan Interaksi Sosial dengan Motivasi Kerja Karyawan PT Perkebunan Nusantara II. Jurnal Penelitian Pendidikan, Psikologi dan Kesehatan (J-P3K), 1 (3): 218-223. 


\section{PENDAHULUAN}

Setiap perusahaan harus memiliki strategi dalam mencapai dan mewujudkan kesuksesan di dalam perusahaan. Salah satunya adalah dengan memiliki sumber daya manusia yang dapat memajukan perusahaan. Perusahaan yang sukses adalah perusahaan yang memiliki budaya organisasi yang kuat dan dijalankan oleh seluruh karyawan yang ada di perusahaan tersebut Fuller (Mangkunegara, 2002). Setiap perusahaan mempunyai tujuan untuk mencapai tingkat maksimal dalam mencapai keuntungan. Keuntungan itu bisa diperoleh salah satunya jika perusahaan tersebut ditangani oleh suatu manajemen yang bagus. Disamping itu, kualitas sumber daya manusianya juga sangat memerlukan suatu keberhasilan perusahaan. Apabila perusahaan tersebut memiliki sumber daya manusia yang pandai dan baik untuk memajukan hasil perusahaan. Maka, perusahaan membutuhkan sumber daya manusia yang memiliki motivasi tinggi dalam bekerja untuk mewujudkan keberhasilan dalam perusahaan.

Motivasi adalah dorongan atau penggerak yang hanya diberikan kepada manusia, khususnya kepada para bawahan atau pengikut, yang mempersoalkan bagaimana caranya mendorong gairah kerja bawahan, agar mereka mau bekerja keras dengan memberikan semua kemampuan dan keterampilannya untuk mewujudkan tujuan perusahaan (Ginting, 2004).

Motivasi kerja adalah dorongan yang tumbuh dalam diri seseorang, baik yang berasal dari dalam diri dan luar dirinya untuk melakukan suatu pekerjaan dengan semangat ingin menggunakan semua kemampuan dan keterampilan yang dimilikinya yang bertujuan untuk mendapatkan hasil kerja sehingga mencapai kepuasan sesuai dengan keinginannya. Motivasi kerja adalah suatu proses dimana kebutuhan seseorang mendorongnya untuk melakukan serangkaian kegiatan yang mengarah kepada ketercapaian tujuan tertentu dan bila tujuan tersebut berhasil dicapai akan memuaskan atau memenuhi kebutuhankebutuhan tersebut (Gibson, Ivancevich, \& Donnelly, 1990).

Motivasi kerja sangat penting bagi dunia usaha, karena dengan motivasi kerja yang tinggi maka produktivitas tinggi dapat dicapai. Dengan motivasi yang kuat, daya dorongnya pun kuat untuk meningkatkan kualitas kerjanya. Motivasi dapat diciptakan atau ditingkatkan dengan kemampuan manajemen dalam memenuhi kebutuhan karyawan, memberikan perhatian terhadap bawahannya dan meganggap karyawan sebagai insan yang tidak semata-mata sebagai karyawan. Menggerakkan motivasi kerja karyawan merupakan tugas yang tidak sederhana. Motivasi kerja hanya dapat dilakukan melalui bekerja. Faktor yang mempengaruhi banyak dan beragam, semakin banyak faktor kerja yang mempengaruhi motivasi kerja terpenuhi, maka semakin tinggi semangat semangat kerja karyawan yang bersangkutan (Ginting, 2004).

Menurut McClelland (Munandar, 2001) mengemukakan enam ciri-ciri karyawan bermotivasi tinggi, yaitu memiliki tingkat tanggung jawab pribadi yang tinggi, berani mengambil dan memikul resiko, memiliki tujuan yang realistis, memiliki rencana kerja yang 
menyeluruh dan berjuang untuk merealisasi tujuan, memanfaatkan umpan balik yang konkret dalam semua kegiatan yang dilakukan, dan mencari kesempatan untuk merealisasikan rencana yang telah diprogramkan. Sebaliknya, ciri-ciri karyawan yang memiliki motivasi kerja yang rendah adalah kemampuan bersaing dalam berprestasi rendah, cenderung tidak peduli dengan hasil pekerjaan yang dilakukan, tingkat aspirasi rendah, berorientasi pada saat ini, suka membuang-buang waktu, tidak bertanggung jawab, tidak percaya diri, dan tidak ulet dalam bekerja (Nency, 2007). Terlihat masih ada karyawam yang tidak menggunakan atribut kerja yang aman saat bekerja, hal ini menunjukkan motivasi kerja karyawan yang rendah.

Herzberg mengatakan salah satu yang mempengaruhi motivasi kerja karyawan menjadi tinggi adalah hubungan antar pribadi (interaksi sosial) dimana adanya hubungan kerja yang bisa membuat nyaman dengan saling berkumpul serta berinteraksi antar sesama karyawan (Nency, 2007). Interaksi sosial adalah hubungan timbal balik yang saling mempengaruhi dalam masyarakat. Ada aksi dan ada reaksi, pelakunya lebih dari satu individu dengan individu, kelompok dengan kelompok. Interaksi sosial tidak mungkin terjadi apabila tidak memenuhi syarat yaitu syarat kontak sosial dan komunikasi (Bolman, 1998). Kontak sosial dapat terjadi antara individu dengan individu, antara kelompok dengan kelompok. Sementara komunikasi baik verbal dan non verbal merupakan saluran untuk menyampaikan perasaan ataupun ide/pikiran dan sekaligus sebagai media untuk dapat menafsirkan atau memahami pikiran atau perasaan orang lain (Nency, 2007).

Menurut Soekanto (1991) mengemukakan bahwa interaksi sosial adalah hubungan antara orang per orang atau orang dengan kelompok manusia. Ada empat pola interaksi sosial, yaitu kerja sama (cooperation), persaingan (competition), pertentangan (conflict), dan akomodasi (accommodation). Sedangkan menurut Gondokusumo (Nency, 2007) interaksi sosial adalah suatu hubungan antara individu atau lebih, dimana kelakuan individu yang satu mempengaruhi, mengubah, atau memperbaiki kelakuan individu yang lain atau sebaliknya.

Mengacu pada hal diatas peneliti tertarik melakukan penelitian dengan judul "Hubungan Interaksi Sosial dengan Motivasi Kerja Karyawan PT. Perkebunan Nusantara II (Persero) Kebun Tanjung Garbus-Pagar Merbau.

\section{METODE PENELITIAN}

Variabel penelitian dalam penelitian ini meliputi dua variabel, yaitu variabel terikat (motivasi kerja) dan variabel bebas (interaksi sosial). Populasi dalam penelitian ini adalah karyawam pabrik kelapa sawit PT. Perkebunan Nusantara II yang berjumlah 74 orang. Teknik pengambilan sampel menggunakan Total Sampling yaitu keseluruhan populasi digunakan sebagai subjek penelitian karena jumlah populasi yang kurang dari 100 maka seluruh populasi dijadikan sampel penelitian semuanya. (Sugiyono, 2013)

Metode pengumpulan data yang digunakan sebagai alat ukur dalam penelitian adalah menggunakan metode skala. Skala yang digunakan dalam penelitian ini yaitu skala interkasi sosial dan skala motivasi kerja. Skala interaksi sosial disusun berdasarkan aspek-aspek interkasi sosial yang dikemukakan oleh Soekanto (1991) yaitu adanya kontak sosial, adanya komunikasi, adanya 
kerjasama, dan adanya respon kedua belah pihak. Skala motivasi kerja disusun berdasarkan aspek-aspek motivasi kerja yang disusun oleh Jurgensen (Ibrahim, 1999), yaitu rasa aman, kesempatan untuk maju, nama baik tempat kerja, teman sekerja, jenis pekerjaan, atasan yang menyenangkan, jam kerja, keadaan tempat kerja yang baik, dan fasilitasfasilitas lain yang disediakan.

Penelitian ini menggunakan analisis statistic dengan program komputer SPSS versi 17.0. Teknik analisis data yang digunakan untuk mengetahui hubungan antara interaksi sosial dan motivasi kerja adalah analisis korelasi $r$ Product Moment. Peneliti menggunakan metode analisis korelasi $r$ Product Moment karena metode ini dipandang tepat digunakan untuk mengetahui ada tidaknya hubungan interaksi sosial dengan motivasi kerja pada karyawan dan untuk mengetahui arah hubungan antar variabel tersebut.

\section{HASIL DAN PEMBAHASAN}

Subjek penelitian yang digunakan dalam penelitian ini adalah karyawan PT. Perkebunan Nusantara II (Persero) Tanjung Garbus Pagar Merbau sebanyak 74 orang. Penelitian dilaksanakan pada tanggal 19 November 2015 dengan menggunakan sistem tryout terpakai, artinya sampel yang sudah digunakan dalam uji coba skala ukur digunakan kembali sebagai sampel penelitian untuk pengujian hipotesis.

Berdasarkan hasil uji coba skala interkasi sosial yang berisi 41 butir aitem dengan format skala Likert, maka didapatkan 40 aitem yang valid dan 1 aitem yang gugur dengan koefisien validitas butir yang valid bergerak dari nilai $\mathrm{rbt}=0,480$ sampai $\mathrm{rbt}=0,651$. Indeks reliabilitas yang diperoleh sebesar 0,948 sehingga skala sebagai alat ukur dapat dikategorikan handal. Sedangkan pada skala motivasi kerja yang berisi 48 butir pernyataan terdapat butir yang gugur sebanyak 10 butir dan butir yang valid ada 38 butir. Koefisien validitas butir yang valid bergerak dari nilai $\mathrm{rbt}=0,300$ sampai $\mathrm{rbt}=0,538$. Indeks reliabilitas yang diperoleh sebesar 0,906 sehingga skala sebagai alat ukur dapat dikategorikan handal.

Setelah dilakukan uji validitas dan reliabilitas pada kedua variabel maka selanjutnya sebelum data dianalisis terlebih dahulu dilakukan uji asumsi terhadap variabel yakni variabel interaksi sosial dan variabel motivasi kerja, yang meliputi uji normalitas sebaran dan uji linearitas hubungan. Pengujian dan analisis data dilakukan dengan menggunakan program SPSS for Windows 17.0.

Berdasarkan hasil analisis dengan metode analisis korelasi Product Moment, diketahui bahwa terdapat hubungan positif yang signifikan antara Interaksi Sosial dengan Motivasi Kerja, dimana $\mathrm{r}_{\mathrm{xy}}=$ 0,397; $\mathrm{p}=0,000<0,010$. Artinya ada hubungan antara interaksi sosial dengan motivasi kerja karyawan di PT Perkebunan Nusantara II, di mana semakin baik Interaksi sosial, maka semakin tinggi Motivasi Kerja, dinyatakan hipotesis diterima.

\begin{tabular}{llllll}
$\begin{array}{l}\text { Tabel 1. Rangkuman } \\
\text { Product Moment }\end{array}$ & Hasil & Analisis & Korelasi \\
\hline Statistik & $\begin{array}{l}\text { Koefisien } \\
\left(\mathrm{r}_{\mathrm{xy}}\right)\end{array}$ & $\mathrm{R}^{2}$ & Sig & BE\% & Ket \\
\hline $\mathrm{X}-\mathrm{Y}$ & 0,397 & 0,158 & 0,000 & 15,8 & $\mathrm{~S}$ \\
\hline
\end{tabular}


Berdasarkan tabel diatas diketahui koefisien determinan $\left(\mathrm{r}^{2}\right)$ dari hubungan antara variabel bebas $\mathrm{X}$ dengan variabel terikat $Y$ adalah sebesar $r^{2}=0,158$. Ini menunjukkan bahwa Motivasi Kerja dibentuk oleh Interaksi Sosial sebesar 15,8\%. Interaksi sosial memiliki peran yang penting untuk timbulnya motivasi kerja pada karyawan.

Berdasarkan hasil perhitungan mean hipotetik dan mean empirik, pada rangkuman dibawah ini.

Tabel 1. Hasil Perhitungan Nilai Rata-rata Hipotetik dan Nilai Rata-rata Empirik

\begin{tabular}{lllll}
\hline & \multicolumn{4}{l}{ Nilai Rata-rata } \\
Variabel & SD & $\begin{array}{l}\text { Hipot } \\
\text { etik }\end{array}$ & Empirik & Ket \\
\hline $\begin{array}{l}\text { Interaksi } \\
\text { Sosial }\end{array}$ & 14,359 & 100 & 119,135 & Baik \\
$\begin{array}{l}\text { Motivasi } \\
\text { Kerja }\end{array}$ & 12,444 & 95 & 116,648 & Tinggi \\
\hline
\end{tabular}

Dari tabel diatas, perhitungan mean hipotetik dan mean empirik yang menunjukkan interaksi sosial yang diperoleh oleh karyawan di PT Perkebunan Nusantara II pada kategori baik dengan skor mean hipotetik 100 dan mean empirik 119,135 serta standar deviasi nya 14,359 . Sedangkan motivasi kerja karyawan di PT Perkebunan Nusantara II pada kategori tinggi dengan skor mean hipotetiknya 95 dan mean empirik 116,648 serta standar deviasinya 12,444 .

Hal ini menunjukkan bahwa kondisi interaksi sosial yang baik pada karyawan PT Perkebunan Nusantara II meningkatkan timbulnya motivasi kerja pada karyawan PT Perkebunan Nusantara II. Hasil penelitian ini yang melibatkan seluruh karyawan menunjukkan interaksi sosial karyawan pada kategori baik sehingga motivasi kerja karyawan pada kategori tinggi.

\section{SIMPULAN}

Berdasarkan hasil analisis dari pembahasan maka hal-hal yang dapat peneliti simpulkan sebagai berikut:

Berdasarkan hasil analisis dengan metode analisis korelasi Product Moment, diketahui bahwa terdapat hubungan positif yang signifikan antara Interaksi Sosial dengan Motivasi Kerja, dimana $r_{x y}=$ 0,$397 ; \mathrm{p}=0,000<0,010$. Artinya semakin baik interaksi sosial maka semakin tinggi motivasi kerja.

Koefisien determinan $\left(\mathrm{r}^{2}\right)$ dari hubungan antara variabel bebas $\mathrm{X}$ dengan variabel terikat $\mathrm{Y}$ adalah sebesar $\mathrm{r}^{2}=$ 0,158 . Ini menunjukkan bahwa Motivasi Kerja dibentuk oleh Interaksi Sosial sebesar 15,8\%. Dimana perhitungan mean hipotetik dan mean empirik yang menunjukkan interaksi sosial yang diperoleh para karyawan di PT Perkebunan Nusantara II pada kategori baik dengan skor mean hipotetik 100 dan mean empirik 119,135 serta standar deviasi nya 14,359 . Sedangkan motivasi kerja karyawan di PT Perkebunan Nusantara II pada kategori tinggi dengan skor mean hipotetiknya 95 dan mean empirik 116,648 serta standar deviasinya 12,444 .

\section{DAFTAR PUSTAKA}

Bolman, E. G. (1998). Effective Small Group Communication. Minnesotta: Burgess Publishing Company.

Gibson, J. L., Ivancevich, J. M., \& Donnelly, J. H. (1990). Organisasi: Perilaku, Struktur, Proses. Jakarta: Erlangga.

Ginting, L. (2004). Hubungan Antara Persepsi Terhadap Makna Kerja Dengan Motivasi Kerja Para Pegawai Biro di POLDA 
Sumatera Utara. Medan: Fakultas Psikologi Universitas Medan Area.

Ibrahim. (1999). Aspek-aspek dalam Motivasi Kerja.

Mangkunegara. (2002). Sumber Daya Manusia Perusahaan. Bandung: Rosdakarya.

Munandar, A. S. (2001). Psikologi Industri Organisasi. Jakarta: Universitas Indonesia.

Nency, Y. F. (2007). Hubungan Kepuasan Kerja Dengan Motivasi Kerja Karyawan (Studi di PT PLN (Persero) Distribusi Jawa Timur Area Pelayanan dan Jaringan Malang). Malang: Universitas Islam Negeri Malang.

Soekanto, S. (1991). Suatu Pengantar Sosiologi. Jakarta: Rajawali Press.

Sugiyono. (2013). Metode Penelitian Pendidikan Pendekatan Kualitatif, Kuantitatif, dan $R \mathcal{E} D$. Bandung: Alfabeta. 